\begin{tabular}{cc|c}
\hline Tar. Bil. Der. & Journal of Agricultural Sciences \\
& $\begin{array}{c}\text { Dergi web sayfası: } \\
\text { www.agri.ankara.edu.tr/dergi }\end{array}$ & Journal homepage: \\
& www.agri.ankara.edu.tr/journal
\end{tabular}

\title{
Influence of Different Cutting Dates on Cornell Net Carbohydrate and Protein System (CNCPS) Parameters and the Fatty Acid Compositons of Caramba Hay (Lolium multiflorum cv. caramba)
}

\author{
Muazzez Cömert ACAR ${ }^{a}$, Hülya ÖZELÇAM ${ }^{a}$, Yilmaz ŞAYAN ${ }^{b}$, Bülent BUDAK ${ }^{c}$ \\ ${ }^{a}$ Department of Animal Science, Faculty of Agriculture, University of Ege, 35100 Bornova, Izmir, TURKEY

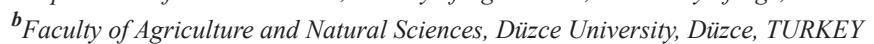 \\ ${ }^{c}$ Seed Programme, Ödemiş Vocational School of Ege University, Ödemiş, İzmir, TURKEY
}

\section{ARTICLE INFO}

Research Article

DOI: 10.15832 /ankutbd.422710

Corresponding Author: Muazzez Cömert ACAR, E-mail: muazzez.comert@ege.edu.tr, Tel: +90 (232) 3114464 Received: 10 May 2018, Received in Revised Form: 02 July 2018, Accepted: 15 July 2018

\begin{abstract}
The aim of the study was to determine the influence of different cutting dates on Cornell Net Carbohydrate and Protein System (CNCPS) parameters and the fatty acid (FAs) compositons of caramba hay (Lolium multiflorum cv caramba). The samples were taken from the five randomized plots at the three different cuts (first cut:before blossom, second cut:blossom $50 \%$, and third cut:after blossom). The samples were analyzed including the crude protein (CP), ether extract $(E E), C P$ fractions $\left(A=N P N, B_{1}=\right.$ fast, $B_{2}=$ intermediate, $B_{3}=$ slow and $C=$ not fermented and available for the animal), degradable intake protein (DIP), undegradable intake protein (UIP) and the FAs compositions (C14:0, C16:0, $\mathrm{C} 18: 0, \mathrm{C} 18: 1, \mathrm{C} 18: 2$ and $\mathrm{C} 18: 3)$. The $\mathrm{CP}, \mathrm{EE}$ and $\mathrm{A}_{1}$ fraction were negatively affected by the different cutting dates $(\mathrm{P}<0.05)$, while the $\mathrm{B}_{2}, \mathrm{~B}_{3}$ and $\mathrm{C}$ fractions were increased by growing stage $(\mathrm{P}<0.05)$. Different cutting dates affected total major FAs, and decreased the concentration of $\mathrm{C} 18: 3(\mathrm{P}<0.05)$ and increased those $\mathrm{C} 16: 0(\mathrm{P}<0.05)$ and $\mathrm{C} 18: 2$ $(\mathrm{P}>0.05)$. A positive strong linear relation was found between the $\mathrm{C} 18: 3$ and $\mathrm{CP}$ contents in caramba hay $\left(\mathrm{R}^{2}=0.769\right.$, $\mathrm{P}<0.001)$. The study showed that $\mathrm{CP}$, soluble protein $\left(\mathrm{A}+\mathrm{B}_{1}\right.$ fraction) and $\mathrm{C} 18: 3$ were significantly decreased, the other crude protein fractions $\left(\mathrm{B}_{2}, \mathrm{~B}_{3}\right.$ and $\left.\mathrm{C}\right)$ and other major FAs (C16:0 and $\left.\mathrm{C} 18: 2\right)$ were increased by growing stage.

Keywords: CNCPS parameters; Fatty acids; Cutting date; Caramba
\end{abstract}

(C) Ankara Üniversitesi Ziraat Fakültesi

\section{Introduction}

Caramba (Lolium multiflorum, cv. caramba) which is a perennial forage grass, is rich especially protein, minerals and water-soluble carbohydrate content. Further its stem does not mature quickly until the time of harvest (Dewhurst et al 2001). In recent years it is stated that caramba is quite well adapted to Turkey climate and soil condition, so caramba has been recognized as potential forage for ruminant animals (Özelçam et al 2015). The livestock breeding in Turkey is largely based on pasture. However, because of agricultural mechanization, total range or pasture areas of Turkey have been drastically reduced (Kusvuran \& Tans1 2011). 
It is very important to know the crude protein (CP) fractions and total fatty acids (FAs) of the dietary feedstuffs to determine diet composition for target milk or meat composition (Ferlay et al 2006). The CP and FAs of perennial forages are affected by numerous factors such as plant species and variety, climate, day length, rainfall, fertilization, stage of growth and storage methods (Amrane \& Michalet-Doreau 1993; Aganga et al 2004; Kalač \& Samková 2010). In perennial grasses, the highest level of CP and the C18:3 content of FAs in young plants at the first cut, and then it decreases during summer, particularly around blooming (Dewhurst et al 2001; Boufaïed et al 2003). Also, knowledge of the factors that influence the $\mathrm{CP}$ and FAs of forages could help farmers to optimize cultivation and harvest conditions and thereby improve the quality of their forages (Khan et al 2012). The efficiency of nitrogen use and decrease nitrogen excretion to the environment is the important sustainability parameters on ruminant farms (Haugen et al 2006). The organic forages are the most necessary key to prevent the protein deficiency in organic ruminant rations, so forage protein analysis comes on the top of the list in accurately formulating rations (Pacheco et al 2012). Some researchers stated that rumen $\mathrm{CP}$ degradability may be reliably predicted from Cornell Net Carbohydrate and Protein System (CNCPS) parameters (Shannak et al 2000; Branco et al 2012). The perennial grass has been used as an animal feed as a fresh grass with grazing or after the processes of silage making or haymaking. The important losses occur in the content of FAs in perennial ryegrass, because of the loss of precursor fatty acids during the processes of silage making or haymaking. Therefore, the major FAs of fresh caramba are higher than silage or hay forms (Aii et al 1988). Although hays contain relatively low level of FAs on lipids, they are cheapest and often the major source of unsaturated FAs in ruminant diets (Kalač \& Samková 2010). Also, the data on chemical composition and the FAs of caramba hay have been scarce compared with fresh or silage forms (Glasser et al 2013; Özelçam et al 2015).
The objective of the study was to investigate the influence of three cutting dates on CNCPS parameters and the FAs compositons of caramba hay.

\section{Material and Methods}

In this study, caramba (Lolium multiflorum $c v$. Caramba) is used as the material from Küçük Menderes basin at the Aegean Region which has the characteristics of Mediterranean climate. The summer season is warm and dry, and winters are temperate and rainy. The caramba was planted the research plots of Ege University, Ödemiş Vocational School Experiment Farm at Izmir (38 $13^{\prime} 03^{\prime \prime}$ North, $27^{\circ} 57^{\prime} 50^{\prime \prime}$ East) from November in 2010 to June in 2011. Caramba samples were taken from the five randomized plots $(2 \mathrm{~m} \times 5 \mathrm{~m})$ of the experimental farm at the three cuts of 2011 year. The three cuts were the first cut (before blossom), second cut (50\%, blossom) and third cut (after blossom). The dry matter (DM) contents of the fresh caramba were $180.1,200.1$ and $264.7 \mathrm{~g} \mathrm{~kg}^{-1}$ for the first cut, second cut and third cut, respectively.

\subsection{The climate, soil, planting and harvesting conditions}

The soil and climate conditions of the experimental farm did not show a restrictive effect on caramba planting in irrigated conditions. The average temperature is $15.3{ }^{\circ} \mathrm{C}$ and total rainfall precipitation is $510 \mathrm{~mm}$ from November in 2010 to June in 2011 (Anonymous 2014). The soil $(0-20 \mathrm{~cm})$ where the study conducted had $\mathrm{pH} 7.28$, salt $0.030-0.095 \%$, organic matter $1.13-1.58 \%, \mathrm{CaCO}_{3} 1.44-21.52 \%$, $\mathrm{N} 0.11-0.16 \%$, P $20.50-40.52 \mathrm{mg} \mathrm{kg}{ }^{-1}$, K $110-$ $400 \mathrm{mg} \mathrm{kg}^{-1}$. The soil was generally sandy-loam texture. In the experiment, the raw spacing was 20 $\mathrm{cm}$ and the amount of the seed per hectare was 25 $\mathrm{kg}$. Before planting, the plots were received $50 \mathrm{~kg}$ $\mathrm{N}$ (nitrogen) and $\mathrm{P}_{2} \mathrm{O}_{5}$ (phosphorus) per hectare by taking 15.15.15 compose base fertilizer. In spring, each plot was received $50 \mathrm{~kg} \mathrm{~N}$ per hectare as base application. Harvesting were made at $4-5 \mathrm{~cm}$ height at the before blossom, blossom $(50, \%)$ and after blossom. 


\subsection{The chemical compositions and the Cornell net carbohydrate and protein system parameters}

The DM, CP and ether extract (EE) values of the caramba hay (air-dried samples) were measured by AOAC-approved methods (AOAC 1995). The standardized method of Licitra et al (1996) was used to determine the CNCPS parameters. The caramba hay samples were grinded using $1 \mathrm{~mm}$ sieve. The A fraction (non-protein nitrogen/NPN) is traditionally the nitrogen passing into the filtrate after precipitation with tungstic acid. The $\mathrm{B}_{1}$ fraction is true soluble protein in borate-phosphate buffer at rumen $\mathrm{pH}(6.7-$ 6.8). The Whatman\#54 filter paper was used for filtration without vacuum to determine the $A$ and $B_{1}$ fractions. The $\mathrm{A}+\mathrm{B}_{1}$ fractions generate total soluble protein (SolP). The cell wall components of neutral detergent fiber (NDF) and acid detergent fiber (ADF) were determined by Van Soest (1994). After the residue paper of NDF and ADF were transferred into a Kjeldhal flask for protein determination of neutral detergent insoluble protein (NDIP) and acid detergent insoluble protein (ADIP). Degradable intake protein (DIP, $\mathrm{g} \mathrm{kg}^{-1} \mathrm{DM}$ ) was calculated by using the following equations and undegradable intake protein (UIP) was calculated by CP-DIP. The equations: A fraction (NPN): RDPA, rumen soluble protein; $\mathrm{B}_{1}$ fraction (fast soluble protein): $\mathrm{RDPB}_{1}$, $\left(\mathrm{B}_{1} \mathrm{x}\left(\mathrm{Kd}_{\mathrm{B1}} / \mathrm{Kd}_{\mathrm{B1}}+\mathrm{Kp}_{1 \mathrm{x}}\right)\right)$; $\mathrm{B}_{2}$ fraction (intermediate degradable protein): $\mathrm{RDPB}_{2}:\left(\mathrm{B}_{2} \mathrm{x}\left(\mathrm{Kd}_{\mathrm{B} 2} / \mathrm{Kd}_{\mathrm{B} 2}+\mathrm{Kp}_{1 \mathrm{x}}\right)\right)$; $\mathrm{B}_{3}$ fraction (slow degradable protein): $\mathrm{RDPB}_{3}$, $\left(\mathrm{B}_{3} \mathrm{x}\left(\mathrm{Kd}_{\mathrm{B} 3} / \mathrm{Kd}_{\mathrm{B} 3}+\mathrm{Kp}_{1 \mathrm{x}}\right)\right.$ ); DIP (Degradable intake protein): $\mathrm{RDP}_{\mathrm{TOTAL}}=\mathrm{RDPA}+\mathrm{RDPB}_{1}+\mathrm{RDPB}_{2}+\mathrm{RDPB}_{3}$. In these calculations the values stated in Sniffen et al (1992) and Fox et al (2003) were used for the coefficients of outflow rate on the different levels of DM intake (Kp) and degradation rate of B fractions $(\mathrm{Kd})$, respectively. $\left(\mathrm{DIP}_{1 \mathrm{X}}=\right.$ at $1 \mathrm{x}$ maintenance level of intake, $\mathrm{DIP}_{2 \mathrm{x}}=$ at $2 \mathrm{x}$ maintenance level of intake, and $\mathrm{DIP}_{3 \mathrm{x}}=$ at $3 \mathrm{x}$ maintenance level of intake)

\subsection{The fatty acids (FAs)}

The lipid fraction (approximately $0.5 \mathrm{~g}$ ) from caramba hay was extracted with chloroformmethanol at a ratio of $2: 1$; the lipid was then isolated in the chloroform phase after adjustment of the solvent ratio to 2:2:1 (chloroformmethanolwater, $\mathrm{v} / \mathrm{v}$ ). The chloroform phase was removed and evaporated to dry under vacuum heater below $40{ }^{\circ} \mathrm{C}$ (Folch, Lees \& Sloane-Stanley). The lipid is refluxed with a $1 \mathrm{M}$ solution of potassium hydroxide in $95 \%$ methanol. Then all lipid samples were analyzed using a gas-liquid chromatograph to determine the FAs (Agilent Technologies $6890 \mathrm{~N}$ Network GC System, Anaheim, CA, USA, Thermo Scientific TRACE TR-FAME GC Column; 60 $\mathrm{mL}, 0.25 \mathrm{~mm}$ ID, 0.25 um thick) at the University of Ege, Central Analytical Laboratory. Detector temperature: $250{ }^{\circ} \mathrm{C}$, injection block temperature: $250{ }^{\circ} \mathrm{C}$, Owen temperature: gradually from $2{ }^{\circ} \mathrm{C}$ to $240{ }^{\circ} \mathrm{C}$, Split flow $119.9 \mathrm{~mL} \mathrm{~min}^{-1}$, helium as the carrier gas. The FAs were identified by comparing their retention time and fragmentation pattern with an established standard (SUPELCO 37 Comp. Fame mix $10 \mathrm{mg} \mathrm{mL}^{-1}$ in $\mathrm{CH}_{12} \mathrm{Cl}_{2}$ ). The FAs; saturated (myristic C14:0, palmitic C16:0 and stearic C18:0), monounsaturated (oleic C18:1 and linoleic C 18:2) and polyunsaturated ( $\gamma$-linoleic $\mathrm{C} 18: 3)$ were expressed as the percentages of total lipids.

\subsection{Statistical analyses}

All data were subjected to one-way ANOVA by using the statistical package of SPSS $\left(15.0^{\circledR}\right)$ (SPSS 2006). Significant differences among the means were determined by the Duncan's multiple range tests. The relationship between the values the unsaturated FAs and the CP in caramba hay were determined by stepwise simple linear regressions.

\section{Results and Discussion}

\subsection{The chemical compositions and crude protein fractions}

The results of chemical compositions and CP fractions of caramba hay are shown in Table 1. When the growth period is increased by the different cuts (before blossom, 50\% blossom and after blossom), the results of the $\mathrm{CP}$ and EE were decreased as an expected (Table 1). The differences between these contents were largely due to the different cutting 
dates. The first cut had the highest $\mathrm{CP}$ content of caramba hay compared to the other cuts $(\mathrm{P}<0.05)$. The $\mathrm{CP}$ results in this experiment were agreed with Amrane \& Michalet-Doreau (1993) and Aganga et al (2004) that CP of caramba hay is decreased depending on different cutting dates. Similar to these references, first cut had the highest $\mathrm{CP}$ content. The $\mathrm{CP}$ and EE contents of second cut of caramba hay in the present experiment were close to the CNCPS ver. 5 feedbank data (Fox et al 2003) (respectively, $86.0 \mathrm{~g} \mathrm{~kg}^{-1} \mathrm{DM}$ and $\left.22.0 \mathrm{~g} \mathrm{~kg}^{-1} \mathrm{DM}\right)$. Also, similar to the this study with third cut, Özelçam et al (2015) stated that the CP was $63.5 \mathrm{~g} \mathrm{~kg}^{-1} \mathrm{DM}$ and EE was $18.4 \mathrm{~g} \mathrm{~kg}^{-1} \mathrm{DM}$ in the for caramba hay.

The CNCPS parameters of chemical compositions were compared with the values of the CNCPS ver. 5 feedbank and those determined by Fortina et al (2003). The CNCPS parameters of caramba hay on the CNCPS ver. 5 feedbank were similar to the second cut of the our results (bloosom) except NPN (SolP\%). The average NPN (96 of SolP\%) on the feedbank was higher than in our results for the all cutting times (Table 1). The differences between the NPN could be attributed to the different reagents (tungistic acid vs tricloratic acid) and filtration methods (Fortina et al 2003). However, we used tungistic acid in our study. On the other hand, when we compared our results with Fortina et al (2003), for caramba hay, although CP content $\left(176 \mathrm{~g} \mathrm{~kg}^{-1} \mathrm{DM}\right)$ is higher than our results, SolP (37.2 CP, \%) was very close for the second cut. SolP, NPN (Solp\%) and A fraction of the study were decreased by increasing vegetation stage and this decrease was important for Solp and A fraction $(\mathrm{P}<0.05)$. Similarly, Villiers \& Ryssen (2001) stated that the soluble $\mathrm{N}$ fraction, rate of degradation of the potentially degradable fraction and effective $\mathrm{N}$ degradability of herbage decreases with advancing stage of growth. Also, the results of $\mathrm{B}_{1}$ fraction for the all cuts were low as explained in Sniffen et al (1992) that $B_{1}$ fraction of forages is lower than other fractions. The crude protein fractions of the Fortina et al (2003) study were close to the results for A, $B_{1}$ and $\mathrm{B}_{2}$ fractions, were higher for $\mathrm{B}_{3}$ fractions and lower for $\mathrm{C}$ fractions. The variations for the $\mathrm{B}_{3}$ and $\mathrm{C}$ fractions could be due to the conventional or filter bag methods to determine NDIP and ADIP (Bovera et al 2003). Like Polat et al (2014), DIP values decreased and UIP values increased in accordance with the increased feeding level of DM intake (1x,

Table 1- Chemical compositions and crude protein fractions of caramba hay

\begin{tabular}{lllll}
\hline Parameters & $\begin{array}{l}1^{\text {st }} \text { cut } \\
\text { (Before blossom) }\end{array}$ & $\begin{array}{l}2^{\text {nd }} \text { cut } \\
\text { (Blossom, 50\%) }\end{array}$ & $\begin{array}{l}3^{\text {th }} \text { cut } \\
\text { (After blossom) }\end{array}$ & P value \\
\hline $\mathrm{DM}, \mathrm{g} \mathrm{kg}^{-1}$ & $923.50 \pm 1.70 \mathrm{~b}$ & $932.20 \pm 1.50 \mathrm{a}$ & $935.50 \pm 0.90 \mathrm{a}$ & 0.003 \\
$\mathrm{CP}, \mathrm{g} \mathrm{kg}^{-1} \mathrm{DM}$ & $106.10 \pm 4.30 \mathrm{a}$ & $92.40 \pm 3.10 \mathrm{~b}$ & $62.70 \pm 3.10 \mathrm{c}$ & 0.000 \\
$\mathrm{EE}, \mathrm{g} \mathrm{kg}^{-1} \mathrm{DM}$ & $28.40 \pm 1.30 \mathrm{a}$ & $24.40 \pm 2.10 \mathrm{ab}$ & $20.30 \pm 1.20 \mathrm{~b}$ & 0.013 \\
SolP, \% of CP & $50.08 \pm 2.01 \mathrm{a}$ & $36.73 \pm 1.59 \mathrm{~b}$ & $17.63 \pm 1.58 \mathrm{c}$ & 0.000 \\
$\mathrm{NPN}, \%$ of SolP & $84.30 \pm 3.32$ & $82.80 \pm 3.99$ & $78.41 \pm 4.58$ & 0.568 \\
NDIP, \% of CP & $24.93 \pm 0.79 \mathrm{c}$ & $32.17 \pm 1.05 \mathrm{~b}$ & $36.95 \pm 1.64 \mathrm{a}$ & 0.000 \\
\hline Crude protein fractions, $\%$ of CP & & & \\
\hline $\mathrm{A}=\mathrm{NPN}$ & $42.44 \pm 2.51 \mathrm{a}$ & $29.97 \pm 1.16 \mathrm{~b}$ & $13.56 \pm 1.37 \mathrm{c}$ & 0.000 \\
$\mathrm{~B}_{1}$ & $7.64 \pm 1.30$ & $6.87 \pm 1.74$ & $5.82 \pm 0.98$ & 0.650 \\
$\mathrm{~B}_{2}$ & $18.76 \pm 1.64 \mathrm{c}$ & $25.96 \pm 2.04 \mathrm{~b}$ & $35.81 \pm 1.62 \mathrm{a}$ & 0.000 \\
$\mathrm{~B}_{3}$ & $18.21 \pm 1.27 \mathrm{~b}$ & $23.69 \pm 1.62 \mathrm{a}$ & $25.35 \pm 1.44 \mathrm{a}$ & 0.005 \\
$\mathrm{C}^{\text {(ADIP) }}$ & $6.72 \pm 0.91 \mathrm{~b}$ & $8.48 \pm 1.15 \mathrm{ab}$ & $11.60 \pm 1.21 \mathrm{a}$ & 0.013 \\
\hline
\end{tabular}

DM, dry matter; CP, crude protein; EE, crude fat; SolP, soluble protein; NPN, nonprotein nitrogen (\% of SolP); NDIP, neutral detergent insoluble protein; A fraction (NPN), non-protein nitrogen; $\mathrm{B}_{1}$, fast true soluble protein; $\mathrm{B}_{2}$, intermediate degradable protein; $\mathrm{B}_{3}$, slow degradable protein; C (ADIP), acid detergent insoluble protein; Different letters (a, b, c) in the same row are statistically different $(\mathrm{P}<0.05)$ 
$2 \mathrm{x}$ and $3 \mathrm{x}$ ) (Figure 1). Because of high protein solubility at the first cut, all DIP values are higher than second and third cuts. Similar to the feeding levels, DIP values were decreased by growing period from the first cut to third cut, all UIP values were significantly increased $(\mathrm{P}<0.05)$. We found $\mathrm{UIP}_{1 \mathrm{X}}$ values of caramba hay according to the first cut, second cut and third cut respectively, 32.19, 33.39 and $34.26 \mathrm{~g} \mathrm{~kg}^{-1}$ DM. Similarly, Fox et al (2003) reported the amount of the UIP ${ }_{1 x}$ values were $30.53 \mathrm{~g} \mathrm{~kg}^{-1} \mathrm{DM}$ for caramba hay.

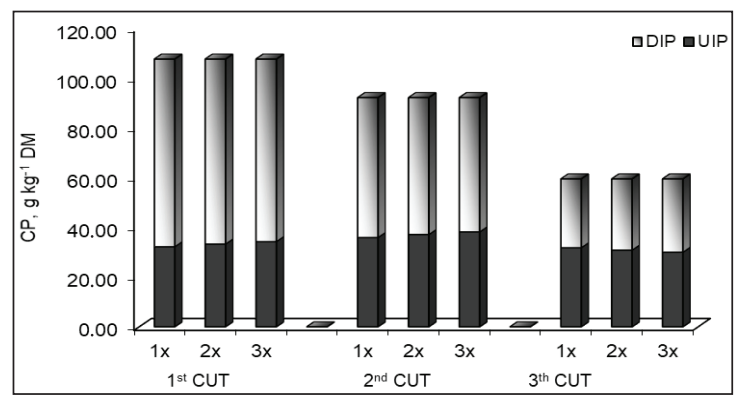

Figure 1-Rumen degradable intake protein (DIP) and Rumen undegradable intake protein (UIP) values of caramba hay according to the DM intakes based on CNCPS. CP, crude protein; DIP, degradable intake protein; UIP, undegradable intake protein (fed at $1 \mathrm{x}$ maintenance level, at $2 x$ maintenance level of intake, and at $3 x$ maintenance level of intake)

\subsection{The fatty acids and relationship between major fatty acids and crude protein}

The FAs of caramba hay with the different cuts are presented in Table 2. The C18:3 was the main
FAs present in caramba hay ranging from first cut $(43.06 \%)$ to third cut $(20.71 \%)$. The other major FAs were $\mathrm{C} 18: 2$ and $\mathrm{C} 16: 0$, which both represented on an average from first cut to third cut $27.93 \%$ and $36.73 \%$, respectively (Table 2). The C14:0, C18:0 and C18:1 represented the lower percent of total FAs. This is in agreement with the finding of Boufaïed et al (2003), Elgersma et al (2005) and Ferlay et al (2006). The C14:0, C16:0, C18:0, $\mathrm{C} 18: 1, \mathrm{C} 18: 2$ and $\mathrm{C} 18: 3$ content of caramba (fresh) were reported as 1.04, 16.7, 1.73, 2.42, 12.3 and $61.0 \%$, respectively (Aii et al 1988). Ferlay et al (2006) confirmed that C14:0, C16:0, C18:0, C18:1, $\mathrm{C} 18: 2$ and $\mathrm{C} 18: 3$ content of caramba hay (contain $133 \mathrm{~g} \mathrm{~kg}^{-1} \mathrm{DM}$ of CP) were $0.6,15.8,1.8,2.0,14.0$ and $55.9 \%$, respectively. Ferlay et al (2006) study was close to our study than Glasser et al (2013). Because, as reported in Glasser et al (2013) that haymaking induced a slight decrease in total fat and FAs, among the FA a decrease in C18:3, mainly compensated for by an increase in C16:1. Even this decrease in C18:3 were higher when the drying conditions were not good, because of lipolysis and oxidation of polyunsaturated FAs (Aii et al 1988).

Similar to the study, Dewhurst et al (2001) concluded that the $\mathrm{C} 18: 3$ of major FAs content (20.4 $\mathrm{g} \mathrm{kg}^{-1} \mathrm{DM}$ ) were highest in early season and cutting date were found significantly important for Lolium multiflorum $(\mathrm{n}=4, \mathrm{P}<0.001)$. This high concentration of C18:3 in first cut (early summer), were explained by Elgersma et al (2005) for perennial ryegrass that the leaf-stem ratio of the herbage probably has effect on FAs content. After first cut, total FAs contained

Table 2- The major fatty acids of caramba hay

\begin{tabular}{lllcl}
\hline $\begin{array}{l}\text { The fatty acids } \\
\text { (g 100 } \mathrm{g}^{-1} \text { lipid extract) }\end{array}$ & $\begin{array}{l}\mathrm{s}^{\text {st }} \text { cut } \\
\text { (Before blossom) }\end{array}$ & $\begin{array}{l}2^{\text {nd }} \text { cut } \\
\text { (Blossom, 50\%) }\end{array}$ & $\begin{array}{l}3^{\text {th }} \text { cut } \\
\text { (After blossom) }\end{array}$ & P value \\
\hline C14:0 & $0.71 \pm 0.01$ & $0.74 \pm 0.07$ & $0.96 \pm 0.03$ & 0.065 \\
C16:0 & $15.40 \pm 0.60 \mathrm{~b}$ & $17.87 \pm 1.13 \mathrm{~b}$ & $20.61 \pm 0.20 \mathrm{a}$ & 0.003 \\
$\mathrm{C} 18: 0$ & $3.25 \pm 0.37 \mathrm{a}$ & $2.09 \pm 0.14 \mathrm{~b}$ & $3.20 \pm 0.25 \mathrm{a}$ & 0.016 \\
$\mathrm{C} 18: 1$ & $7.99 \pm 1.03 \mathrm{a}$ & $4.88 \pm 0.61 \mathrm{~b}$ & $6.29 \pm 0.61 \mathrm{ab}$ & 0.047 \\
$\mathrm{C} 18: 2$ & $12.53 \pm 1.03$ & $14.27 \pm 1.17$ & $16.12 \pm 1.38$ & 0.149 \\
$\mathrm{C} 18: 3$ & $43.06 \pm 0.96 \mathrm{a}$ & $37.96 \pm 3.65 \mathrm{a}$ & $20.71 \pm 1.33 \mathrm{~b}$ & 0.000 \\
Others & $17.10 \pm 1.90 \mathrm{~b}$ & $22.20 \pm 3.00 \mathrm{~b}$ & $31.90 \pm 2.90 \mathrm{a}$ & 0.006 \\
\hline
\end{tabular}

Different letters $(a, b, c)$ in the same row are statistically different $(\mathrm{P}<0.05)$ 
lower concentrations of FAs for caramba hay (Table 2) with the consistent with Dewhurst et al(2001). Glasser et al(2013) reported that predominant factor was the vegetation stage and when the forage grew older, CP decreased, along with the EE, total FAs and the content of C18:3. These variations are first due to the decrease in the proportions of leaves that are richer than stems and seeds in membrane lipids. Also, Witkowska et al (2008) stated that because of lower temperature (the lowest daily total radiation), C18:3 content of FAs in early summer was higher than mid-summer in perennial ryegrass. In line with findings of Elgersma et al (2005), Boufaïed et al (2003) and Witkowska et al (2008), the positive linear relation was found between the content of major FAs (C16:0, C18:2 and C18:3) and CP in caramba hay (Figure 2). The simple regression relationship between $\mathrm{C} 18: 3$ and $\mathrm{CP}\left(\mathrm{n}=15, \mathrm{R}^{2}=0.769, \mathrm{P}<0.001\right)$ was the highest and significantly important compared to C16:0 and C18:2 (Figure 2). This relationship must be a result of indirect associations. Photosynthetic tissue is formed during growth, which is simulated by nitrogen. Furthermore, with the consistent in our study, the relation between the $\mathrm{C} 18: 3$ and crude protein $\left(\mathrm{R}^{2}=0.84, \mathrm{P}<0.001\right)$ was the highest in Boufaïed et al (2003) study compared to the C16:0 and C18:2. However, in our result was disagreement with Boufaïed et al (2003) that the relationship between the C16:0 and C18:2 with crude protein were insignificant.

In conclusion, the crude protein, the soluble protein $\left(\mathrm{A}+\mathrm{B}_{1}\right.$ fraction $)$ and $\mathrm{C} 18: 3$ were significantly decreased by growing stage from first cut to third cut. Because of photosynthetic activity, the plant has a higher CP contents at the first cut and this decreases as the crop ages. On the other (a)

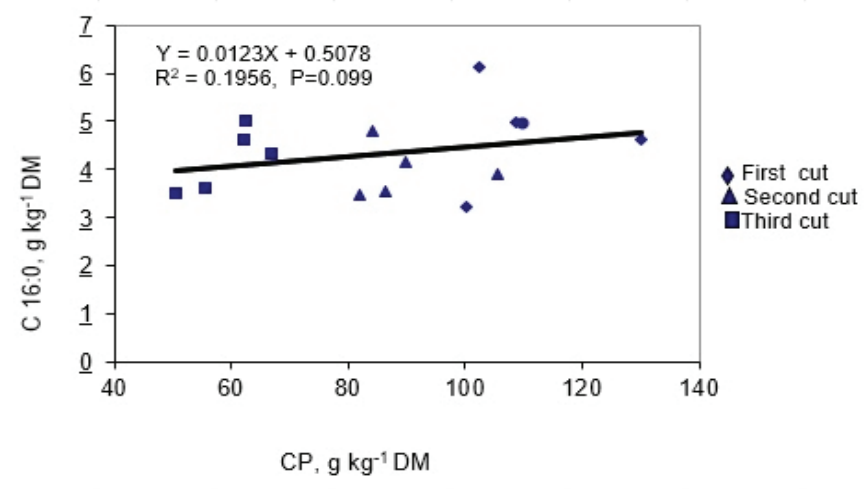

(b)

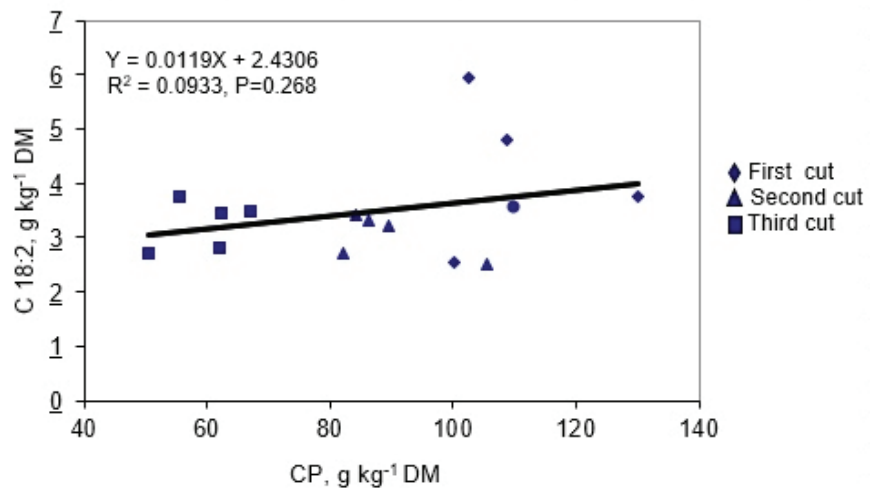

(c)

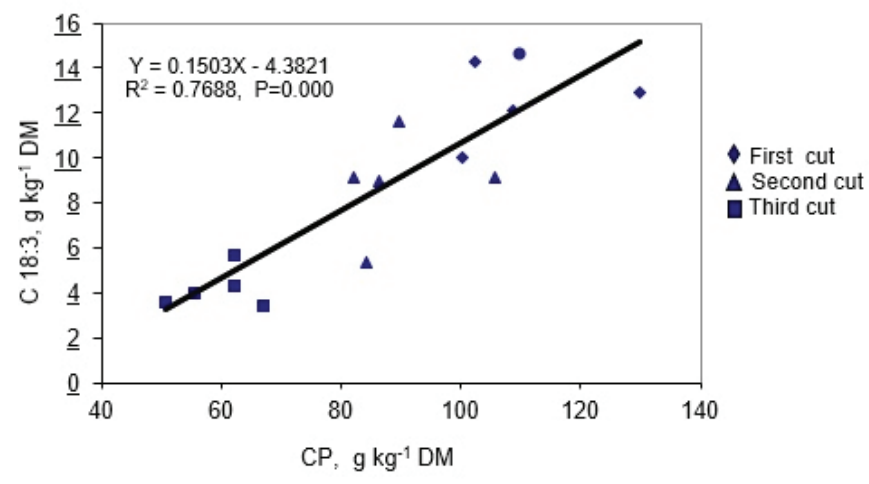

Figure 2- The relationship between the major FAs: C16:0 (a), C18:2 (b), C18:3 (c) and the crude protein in caramba hay harvested at three cutting dates 
side, other $\mathrm{CP}$ fractions $\left(\mathrm{B}_{2}, \mathrm{~B}_{3}\right.$ and $\left.\mathrm{C}\right)$ and major FAs (C16:0 and $\mathrm{C} 18: 2)$ values of in caramba hay were increased from first cut to third cut. Further studies are needed to determine the effects of the growth stage and storage methods on relationship between major fatty acids and $\mathrm{CP}$ in perennial ryegrass.

\section{Acknowledgements}

The authors would like to thank to Technology Research and Application Center of Ege University (EBILTEM-No: 2010/001) for financial supporting.

\section{References}

Aganga A, Omphile U J, Thema T \& Wilson L Z (2004). Chemical composition of ryegrass (Lolium multiflorum) at different stages of growth \& ryegrass silages with addivities. Journal of Biological Science 4(5): 645-649

Aii T, Takahashi S, Kurihara M \& Kume S (1988). The effects of Italian Ryegrass hay haylage \& fresh Italian Ryegrass on the fatty acid composition of cows' milk. Japanese Journal Zootechnican Science 59(8): 718724

Amrane R \& Michalet-Doreau B (1993). Effect of maturity stage of Italian ryegrass \& lucerne on ruminal nitrogen degradability. Annales de zootechnie 42: $31-37$

Anonymous (2014). Turkish State Meteorological Service Meteorological District Office record of climate data. Izmir, Turkey

AOAC (1995). Official Methods of Analysis. (16 $6^{\text {th }}$ Edn) AOAC Publ Washington DC USA

Branco A F, Viana K B, Castañeda R D, Prohmann P E, Coneglian S M \& Mouro G F (2012). Chemical composition and crude protein fractions of coast cross grass under grazing on winter spring and summer in Southern Brazil. Acta Scientiarum Animal Science Maringá 34(2): 183-187

Boufaïed H, Chouinard P Y, Tremblay G F, Petit H V, Michaud R \& Bélanger G (2003). Fatty acids in forages. I. Factors affecting concentrations. Canadian Journal of Animal Science 83(3): 501-511

Bovera F, Spanghero M, Galassi G, Masoero F \& Buccioni A (2003). Repeatability and reproducibility of the Cornell Net Carbohydrate and Protein System analytical determinations. Italian Journal of Animal Science 2: 41-50

Dewhurst R J, Scollan N D, Youell S J, Tweed J K S \& Humphreys M O (2001). Influence of species cutting date and cutting interval on the fatty acid composition of grasses. Grass and Forage Science 56: 68-74

Elgersma A, Maudet P, Witkowska I M \& Wever A C (2005). Effects of nitrogen fertilisation and regrowth period on fatty acid concentrations in perennial ryegrass (Lolium perenne L). Annals of Applied Biology 147: 145-152

Ferlay A, Martin B, Pradel P H, Coulon J B \& Chilliard $Y$ (2006). Influence of grass-based diets on milk fatty acid composition \& milk lipolytic system in Tarentaise \& Montbe'Liarde cow breeds. Journal of Dairy Science 89: 4026-4041

Fortina R, Malfatto V, Mimosi A, Guo K \& Tartari E (2003). The establishment of a database of Italian feeds for the Cornell Net Carbohydrate and Protein System. Italian Journal of Animal Science 2: 171-179

Fox D G, Tylutki T P, Tedeschi L O, Van Amburgh M E, Chase L E, Pell A N, Overton T R \& Russell J B (2003). The Net Carbohydrate and Protein System for evaluating herd nutrition \& nutrient excretion model documentation. (CNCPS version 5.0) July 29 Animal Science Mimeo 213 Department of Animal Science Cornell University 130 Morrison Hall Ithaca New York 14853-4801 pp. 381

Glasser F, Doreau M, Maxin G \& Baumont R (2013). Fat and fatty acid content composition of forages: A metaanalysis. Animal Feed Science and Technology 185: 19-34

Haugen H L, Ivan S K, Mac Donald J C \& Klopfenstein T J (2006). Estimation of undegradable intake protein in forages using neutral detergent insoluble nitrogen at a single in situ incubation time. Journal of Animal Science 84: 651-659

Kalač P \& Samková E (2010). The effects of feeding various forages on fatty acid composition of bovine milk fat: A review. Czech Journal Animal Science 55(12): 521-537

Khan N A, Cone J W, Fievez V \& Hendriks W H (2012). Causes of variation in fatty acid content and composition in grass and maize silages. Animal Feed Science and Technology 174: 36-45

Kusvuran A \& Tans1 V (2011). The effects of different row spacing on herbage and seed yields of annual ryegrass 
(Lolium multiflorum cv caramba). Bulgarian Journal of Agricultural Science 17(6): 744-754

Licitra G, Hernandez T M \& Van Soest P J (1996). Standardization of procedures for nitrogen fractionation of ruminant feeds. Animal Feed Science and Technology 57: 347-358

Özelçam H, Kırkpınar F \& Tan K (2015). Chemical composition In vivo Digestibility \& Metabolizable Energy values of Caramba (Lolium Multiflorum cv Italian ryegrass) Fresh, Silage and Hay. AsianAustralisian Journal of Animal Science 28: 9-10

Pacheco D, Patton R A, Parys C \& Lapierre H (2012). Ability of commercially available dairy ration programs to predict duodenal flows of protein \& essential amino acids in dairy cows. Journal of Dairy Science 95: 937-963

Polat M, Şayan Y \& Özelçam H (2014). Estimating in situ effective crude protein degradability with Cornell Net Carbohydrate and Protein System parameters in energy-rich feedstuffs for ruminants. Kafkas Üniversitesi Veteriner Fakültesi Dergisi 20(2): 259265
Shannak S, Südekum K H \& Susanbeth A (2000). Estimating ruminal crude protein degradation with in situ \& chemical fractionation procedures. Animal Feed Science and Technology 85: 195-214

Sniffen C J, O'Connor J D, Van Soest P J \& Fox D G (1992). A Net Carbohydrate and Protein System for evaluating cattle diets: II Carbohydrate \& protein availability. Journal of Animal Science 70: 3562-3577

SPSS 2006 Released 150 version SPPS IncChicago IL

Van Soest P J (1994). Nutritional Ecology of the Ruminants. $2^{\text {nd }}$ Ed Cornell Univ Press Sage Hause 512 East State Street Ithaca New York 14840 pp. 476

Villiers de J F \& Ryssen van J B J (2001). Performance responses of lambs of various ages to Italian ryegrass (Lolium multiflorum) fertilized with various levels of nitrogen. South African Journal of Animal Science 31(3): 142-148

Witkowska I M, Wever C, Gort G \& Elgersma A (2008). Effects of nitrogen rate and re-growth interval on perennial ryegrass fatty acid content during the growing season. Agronomy Journal 100(5): 13711379 